\title{
Invited Review: Genes Involved in the Bovine Heat Stress Response ${ }^{1}$
}

\author{
R. J. Collier, ${ }^{2}$ J. L. Collier, R. P. Rhoads, and L. H. Baumgard \\ Department of Animal Sciences, University of Arizona, Tucson 85721
}

\begin{abstract}
The cellular heat stress (HS) response is one component of the acute systemic response to HS. Gene networks within and across cells and tissues respond to environmental heat loads above the thermoneutral zone with both intra- and extracellular signals that coordinate cellular and whole-animal metabolism. Activation of these systems appears to be initiated at skin surface temperatures exceeding $35^{\circ} \mathrm{C}$ as animals begin to store heat and rapidly increase evaporative heat loss (EVHL) mechanisms. Gene expression changes include 1) activation of heat shock transcription factor 1 (HSF1); 2) increased expression of heat shock proteins (HSP) and decreased expression and synthesis of other proteins; 3) increased glucose and amino acid oxidation and reduced fatty acid metabolism; 4) endocrine system activation of the stress response; and 5) immune system activation via extracellular secretion of HSP. If the stress persists, these gene expression changes lead to an altered physiological state referred to as "acclimation," a process largely controlled by the endocrine system. In the acclimated state, metabolism is adjusted to minimize detrimental effects of increased thermal heat load. The role of secreted HSP in feedback regulation of the immune and endocrine system has not yet been investigated. The variation in EVHL among animals and the central role that HSF1 has in coordinating thermal tolerance suggest that there is opportunity to improve thermal tolerance via gene manipulation. Determining the basis for altered energy metabolism during thermal stress will lead to opportunities for improved animal performance via altered nutritional management.
\end{abstract}

Key words: heat stress, gene expression, acclimation, metabolism

\section{INTRODUCTION}

The heat stress (HS) response is a highly conserved cascade of protein activation and altered gene expres-

Received July 23, 2007.

Accepted August 21, 2007.

${ }^{1}$ Presented at the ADSA-PSA-AMPA-ASAS Joint Annual Meeting, San Antonio, Texas, July 2007.

${ }^{2}$ Corresponding author: rcollier@ag.arizona.edu sion in response to a variety of stressors (Sonna et al., 2002; Collier et al., 2006). The gene expression component of this network is under heat shock transcription factor (HSF) regulation (Pirkkala et al., 2001; Page et al., 2006). The central role that heat shock proteins (HSP) have in cytoprotection during HS is demonstrated by the fact that HSP overexpression protects against hyperthermia, circulatory shock, and cerebral ischemia during heat stroke (Lee et al., 2006). Traditionally, the HS response is considered an intracellular phenomenon with little or no association with extracellular signaling. However, the premise of this review is that the HS response is fully integrated with the physiological stress response and should be considered as a component of a system-wide gene network coordinated across a variety of cells and tissues to minimize effects of the thermal environment on cellular functions. In addition, the acute endocrine and metabolic responses to thermal stress are, in fact, a component of this signaling network. Considerable work is needed to define these networks and delineate opportunities for improving efficiency of domestic animals in warm environments. Specific examples include understanding genetic regulation of cutaneous evaporative heat loss (EVHL), determining the role of HSF in coordinating cellular metabolism and survival during HS and genetic regulation of nutrient partitioning during thermal stress.

\section{GENES AFFECTING HAIR COAT CHARACTERISTICS}

At temperatures above the thermoneutral zone, respiratory and cutaneous EVHL is the predominant mode of heat loss in dairy cattle (Gebremedhin and Wu, 2001). Physical factors affecting cutaneous EVHL are wind speed, ambient temperature, and relative humidity. Animal factors affecting efficacy of EVHL from the skin surface are sweat gland density and function, hair coat density and thickness, hair length and color, skin color, and regulation of epidermal vascular supply. Absorption of solar radiation due to skin and hair coat color and hair coat density (which affects airflow over the skin surface) are factors that influence EVHL (DaSilva et al., 2003). Genes affecting hair and skin color as 
well as hair length and density have been identified in cattle (Klungland and Vage, 2003; Olson et al., 2003; Mariasegaram et al., 2007). Cattle have an apocrine sweat gland with one sweat gland associated with each hair fiber. Thus, hair density directly affects the number of sweat glands, and hair diameter and length have effects on EVHL by regulating airflow at the skin surface (Gebremedhin and Wu, 2001; Olson et al., 2006). Peak cattle sweating rate has been estimated at 200 to $300 \mathrm{~g} / \mathrm{m}^{2}$ per hour (Berman, 2005), which is only $10 \%$ of the maximum sweating rate of the horse, estimated at $2,000 \mathrm{~g} / \mathrm{m}^{2}$ per hour (McCutcheon and Geor, 2000). These differences are not because of differences in sweat gland type as the horse also has an apocrine sweat gland. This fact and the large variability in cutaneous EVHL between cows suggest that there is opportunity to improve cutaneous EVHL in dairy cattle.

Berman (2005) estimated that effective environmental heat loads above $35^{\circ} \mathrm{C}$ activated the stress response system in lactating dairy cows. We evaluated the impact of surface temperature on rectal temperature and EVHL in dairy cattle. Data were collected from animals in 3 trials conducted at the University of Arizona. The first trial used nonlactating multiparous $(\mathrm{n}=6)$ and nulliparous Holsteins $(\mathrm{n}=6)$ divided into 2 groups under the same temperature-humidity index (THI), varying by the presence or absence of solar radiation as previously reported (Pollard et al., 2004). The second and third trials ( $\mathrm{n}=12$ for each; Pollard et al., 2005) were conducted in the winter and summer of 2004 to study the response to heat acclimation. Briefly, animals were exposed to 3 environments during 3 trials: 1 ) thermoneutral, 2) heat stress, and 3) heat stressing and solar radiation (identical to trial 2 but with solar radiation from 1100 to $1400 \mathrm{~h}$ ). Data were collected over 24 $\mathrm{h}$ on $\mathrm{d} 6$ of each period. With the 3 trials, a large data set of surface and rectal temperatures and EVHL were created across a range of environmental conditions (THI 50 to 83). All data sets were compiled and relationships between parameters were quantified using simple or multilinear regression analysis (SAS Institute Inc., Cary, NC). These studies indicate that dairy cattle are able to maintain body core temperature until skin surface temperature exceeds $35^{\circ} \mathrm{C}$ (Pollard et al., 2005). Above this surface temperature, cows begin to store heat, and rectal temperature rises. Large increases in cutaneous EVHL were detected (Figure 1) above this temperature, and variation between cows is much greater above $35^{\circ} \mathrm{C}$ than below. This is demonstrated by the low correlation between surface temperature and EVHL above $35^{\circ} \mathrm{C}\left(\mathrm{R}^{2}=0.04\right)$ compared with the correlation below $35^{\circ} \mathrm{C},\left(\mathrm{R}^{2}=0.44\right.$, Figure 1$)$. Reasons for this variability are likely because of differences in numbers and activity of glands and hair coat characteristics
(Olson et al., 2006). This information further supports the hypothesis that there is considerable opportunity to improve thermal tolerance in cattle via improved cutaneous EVHL. Respiration rates were also greatly increased above surface temperatures of $35^{\circ} \mathrm{C}$ (Pollard et al., 2004). Thus, genes associated with activation of the systemic HS response (increased respiratory and cutaneous EVHL) are activated at skin surface temperatures below the core temperature of the dairy cow. However, we know very little about the genes regulating EVHL in cattle in response to HS. Recently, Olson et al. (2006) identified a single gene affecting hair coat density and hair length. This gene was also associated with increased EVHL in homozygous cattle under HS conditions (Olson et al., 2006). Additional information is needed on genes associated with regulation of sweat gland function in cattle.

\section{CELLULAR HEAT SHOCK RESPONSE}

\section{Impact of HS on Cellular Functions}

Cellular exposure to elevated temperature induces a number of anomalies in cellular function (Sonna et al., 2002), which include a general inhibition of protein synthesis, defects in protein structure and function, morphological changes due to cytoskeleton rearrangements, shifts in metabolism, alterations in cell membrane dynamics and fluidity, and decreases in cell proliferation. These anomalies invoke large changes in gene transcription and protein synthesis known as the HS response (Lanks, 1986; Lindquist, 1986). The timing and success of these alterations ultimately determines cell survival and acclimation or cell death.

Hyperthermia investigations at the cellular level exhibit substantial variation in experimental models due to type of cell and tissue evaluated. For example, one cell type develops thermal tolerance at a given thermal load, whereas another cell type readily undergoes apoptosis at the same temperature. Despite these inequities in model systems, high ambient heat load will elicit reproducible changes at the transcription factor level.

A transcription factor family known as the HSF has been implicated as important first responders during the onset of elevated cell temperature (Trinklein et al., 2004; Page et al., 2006). These transcription factors coordinate the cellular response to thermal stress and affect expression of a wide variety of genes including HSPs (Akerfelt et al., 2007). The physiological importance of HSF is exemplified by the evolutionary conservation between yeast (Saccharomyces cerevisiae), fruit flies (Drosophila melanogaster), vertebrates, and plants (Pirkkala et al., 2001). Although mammals express HSF 1, 2, and 4, HSF1 is primarily responsible for induc- 


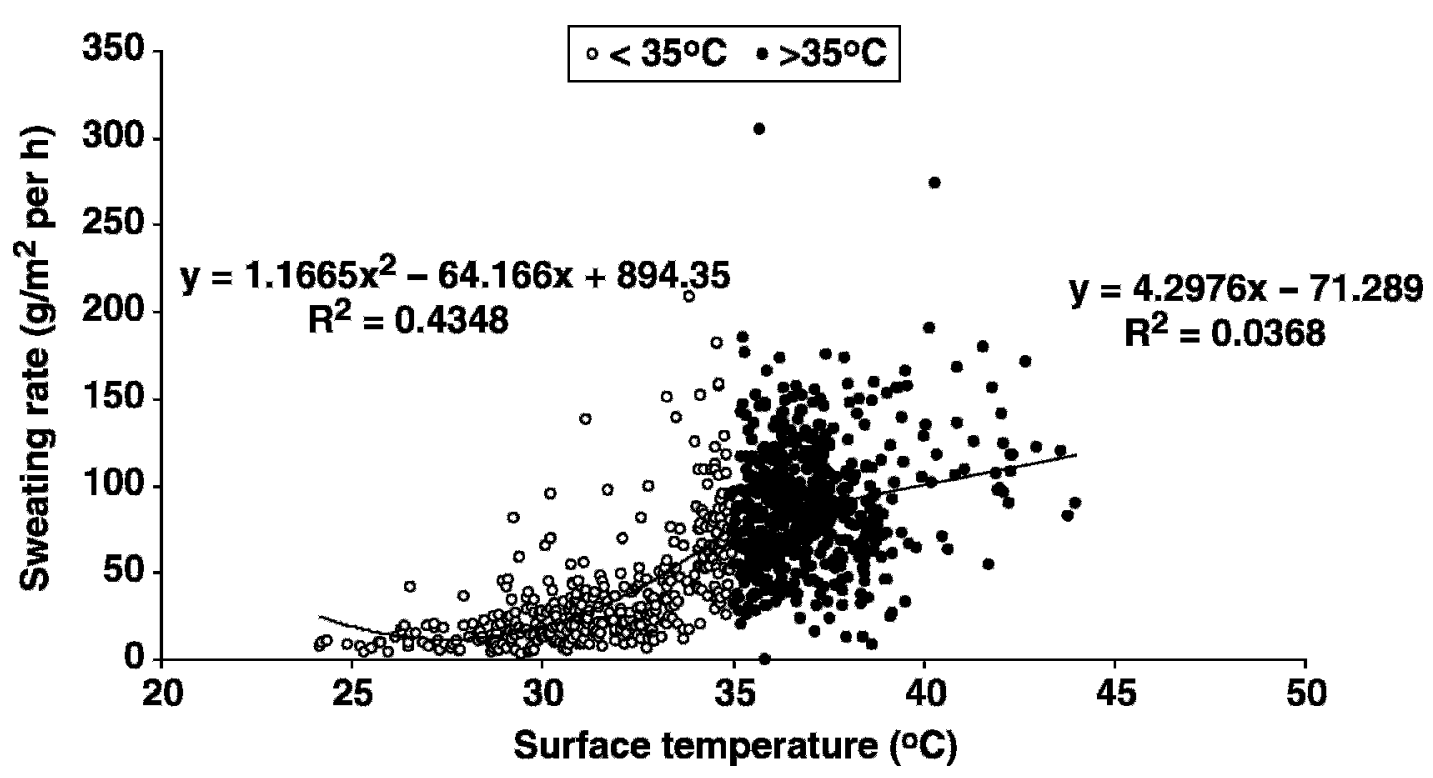

Figure 1. Relationship between infrared coat surface temperature and evaporative heat loss (EVHL) in Holstein dairy cows. Open circles and regression correlation $\left(\mathrm{R}^{2}=0.4348\right)$ denote EVHL below $35^{\circ} \mathrm{C}$. Closed circles and regression correlation $\left(\mathrm{R}^{2}=0.0358\right)$ denote EVHL above $35^{\circ} \mathrm{C}$. Slopes of 2 regressions differ, $P<0.001$.

ing HSP gene expression during hyperthermia (Pirkkala et al., 2001). The current model of HSF1 transcriptional activity indicates that nonstressed cells contain folded HSF1 monomers bound to HSP within the cytoplasm. Upon heat stimulus, the HSP dissociate from HSF1 monomers, which then unfold and bind to 2 other HSF1 monomers to form trimers before their nuclear translocation. Once in the nucleus, homotrimeric HSF1 binds promoters containing heat shock elements (HSE) to activate heat stress target gene transcription. Although HSF1 has traditionally only been associated with regulation of HSP, recent evidence now links it to regulation of carbohydrate metabolism, transport, cytoskeleton, and ubiquitination during HS (Page et al., 2006). The HSF1 gene has been mapped to chromosome 14 in cattle (Winter et al., 2007); however, investigations of HSF1 regulation and function are limited in bovine species despite the importance of HSF1 to the initiation of the HS response.

The lactating dairy cow is particularly sensitive to environmental hyperthermia because metabolic heat load, as a result of milk synthesis, is proportionate to production levels. On a cellular level, coordination should exist between the level of heat strain and adaptation, but only recently have investigators initiated studies aimed at characterizing the global changes in cellular gene expression in cattle. Microarray analysis utilizing bovine-specific cDNA arrays obtained from the National Bovine Functional Genomics Consortium (NBFGC; Suchyta et al., 2003) profiled bovine mam- mary epithelial cell (BMEC) gene expression in response to acute heat stress using an in vitro system that closely approximates mammary development and function (Collier et al., 2006). During the initial period of hyperthermia $\left(42^{\circ} \mathrm{C}\right)$, the BMEC exhibited morphological changes (regression of ductal branches) and reduced cell growth. Consistent with these physical alterations in cell behavior, gene transcripts associated with protein synthesis and cellular metabolism were downregulated. In this model system, HSP 70 gene expression in BMEC remained elevated for $4 \mathrm{~h}$ at $42^{\circ} \mathrm{C}$ before returning to basal levels $8 \mathrm{~h}$ later, signaling the end of thermotolerance and activation of genes associated with apoptosis (Collier et al., 2006).

We wanted to determine if elevation or prolongation of the HSP response in this model would improve thermotolerance (Collier et al., 2007). Prostaglandin $A_{1}$ $\left(\mathbf{P G A}_{1}\right)$ is known to induce HSP synthesis in a variety of mammalian cells resulting in protection against cellular stresses, whereas prostaglandin $\mathrm{E}_{1}\left(\mathbf{P} \mathbf{G E}_{\mathbf{1}}\right)$ is associated with alteration of hypothalamic set point during fever. We tested the effects of $\mathrm{PGA}_{1}$ and $\mathrm{PGE}_{1}$ on HSP 70 gene expression in BMEC using the same model system previously reported (Collier et al., 2006). Primary BMEC were cast in collagen gels using Dulbecco's modified Eagle's medium containing $10 \mu \mathrm{g} / \mathrm{mL}$ insulin, $25 \mu \mathrm{g} / \mathrm{mL}$ epidermal growth factor, $75 \mathrm{ng} / \mathrm{mL}$ IGF-I, $0.1 \% \mathrm{BSA}$, and antibiotic-antimycotic at $37^{\circ} \mathrm{C}$ in $5 \%$ $\mathrm{CO}_{2}$. Cultures grew into ductal structures for $8 \mathrm{~d}$ with media changes at 48--h intervals. On d 9, cultures were 


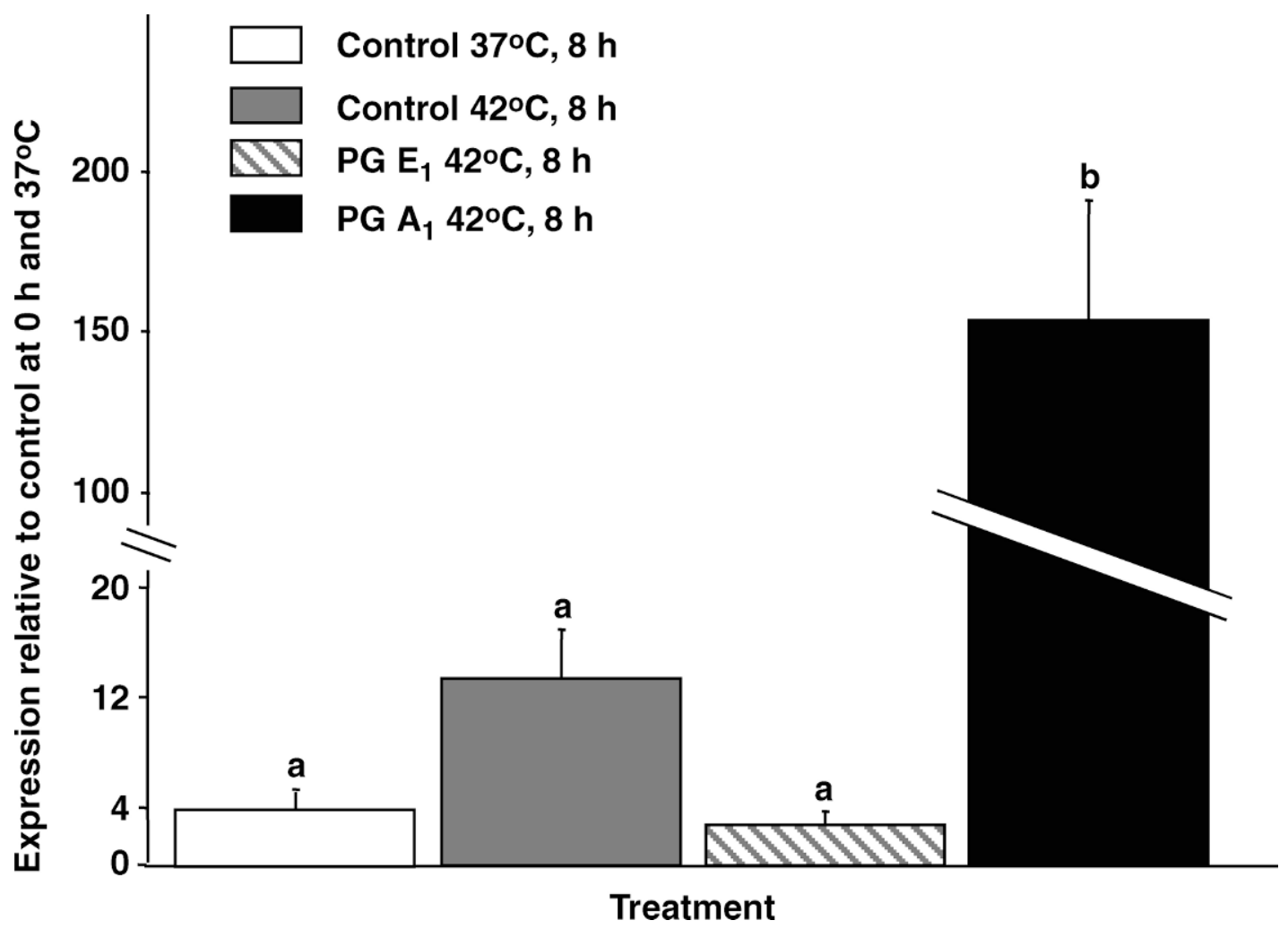

Figure 2. Expression of heat shock protein (HSP)-70 in primary bovine mammary epithelial cells cultured for $8 \mathrm{~h}$ at $42^{\circ} \mathrm{C}$. Both prostaglandin $\mathrm{A}_{1}\left(\mathrm{PGA}_{1}\right)$ and prostaglandin $\mathrm{E}_{1}\left(\mathrm{PGE}_{1}\right)$ are $24 \mu M$ solutions in control media, which is the same as the growth media for $\mathrm{d}$ 1 to 8. Expression (y-axis) is relative to control media at $0 \mathrm{~h}$ and $37^{\circ} \mathrm{C}$. Addition of prostaglandins and exposure to temperature began after $8 \mathrm{~d}$ in culture at $37^{\circ} \mathrm{C}$. Results represent mean of 3 experiments. Different letters indicate significant differences in treatments, $P=0.002$.

divided into 3 groups: controls received the growth medium, another group received growth medium containing $8 \mu \mathrm{g} / \mathrm{mL} \mathrm{PGA}_{1}$, and the final group received growth medium containing $8 \mu \mathrm{g} / \mathrm{mL} \mathrm{PGE}_{1}$. Cultures were then equally divided and moved to thermoneutral $\left(37^{\circ} \mathrm{C}\right)$ or $\mathrm{HS}\left(42^{\circ} \mathrm{C}\right)$ incubators for up to $24 \mathrm{~h}$ with samples removed at $0,1,2,4,8,16,20$, and $24 \mathrm{~h}$. At each time point pictures were obtained of the cultures using a phase contrast microscope with digital imaging capability; 4 collagen cultures were pooled for real-time PCR. Expression of HSP 70 was measured by real timePCR using a BioRad IQ5 system (BioRad, Hercules, CA) with analysis by the delta CT (cycle threshold) method. Hypoxanthine phosphoribosyltransferase 1 (HPRT-1) was used as the housekeeping gene. This study demonstrated that thermotolerance could be extended by the addition of $\mathrm{PGA}_{1}$ to the culture media (Figure 2), by increasing HSP 70 gene expression 150fold over controls during an 8 -h period at $42^{\circ} \mathrm{C}$. Both the rate and duration of HSP 70 gene expression was increased by $\mathrm{PGA}_{1}$. This increase in HS gene expression was associated with improved thermotolerance as demonstrated by the fact that the ductal structures had not collapsed in the PGA-treated cultures but had collapsed in control cultures at the same time and temperature (Figure 3). In agreement, Madin-Darby canine kidney (MDCK) epithelial cells constitutively overexpressing HSP 70 also have improved thermotolerance (Dokladny et al., 2006). In human monocytes, PGA increases HSP gene expression via increased activation of HSF1 (Ella et al., 1999). However, no studies have been conducted to date to determine the mechanism of increase in HSP 70 gene expression in response to $\mathrm{PGA}_{1}$ in the bovine.

An additional lactating dairy cattle study evaluated the gene expression profile of hepatic tissue in response to an extended period (14 d) of HS (Rhoads et al., 2005). The liver's pivotal role in whole-body metabolism (coordination of endogenously and exogenously derived nutrients) is most likely altered by HS-induced reductions in feed intake and shifts in metabolism. In agreement with this notion of hepatic remodeling, liver gene expression favored reductions in cell growth and proliferation and enhanced apoptosis. Overall, the microarray data discussed here demonstrate that bovine cells and tissues undergo similar changes in cellular behavior to other species as previously discussed. 

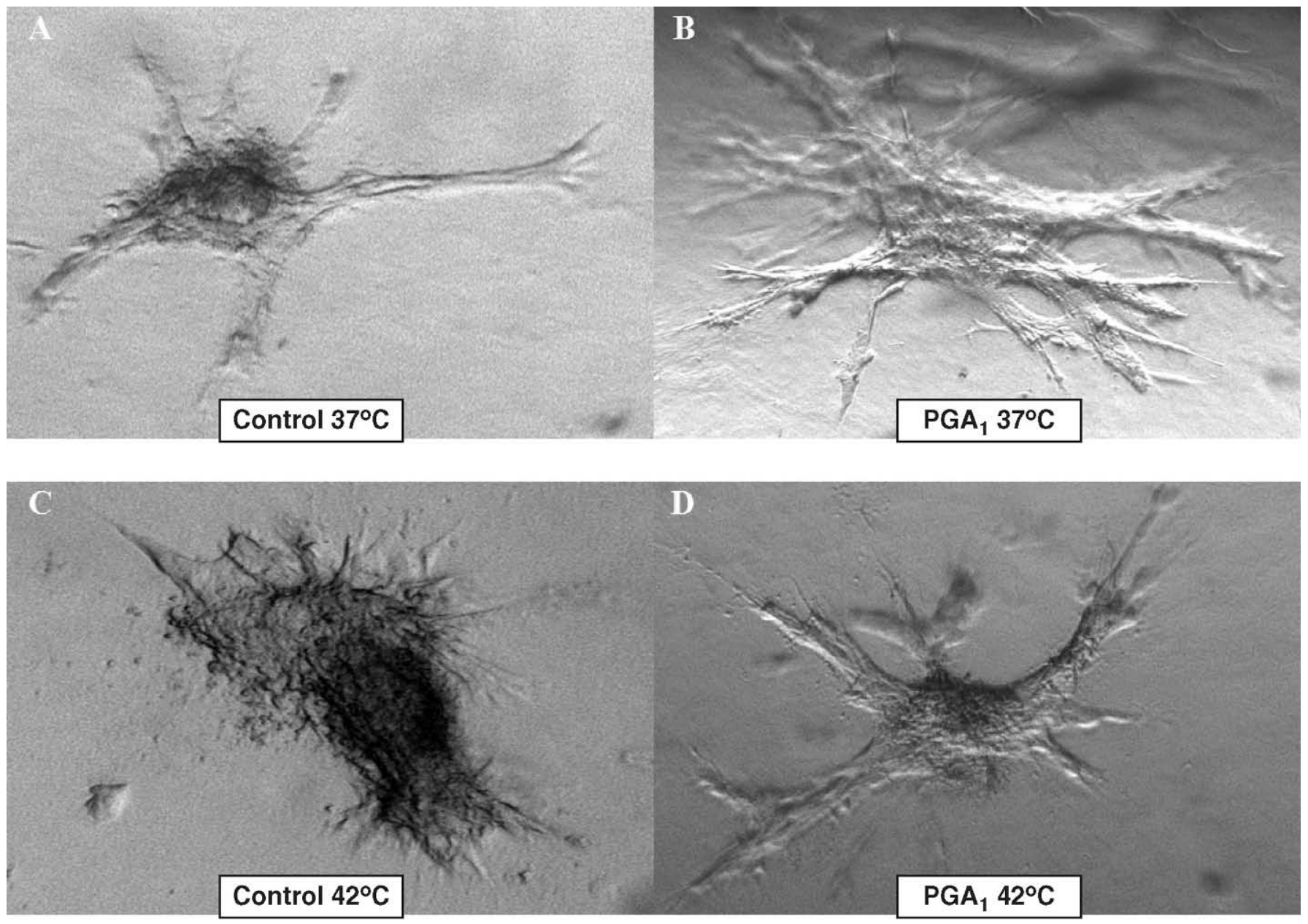

Figure 3. Phase contrast (5×) images of bovine mammary epithelial cells cultured at $37^{\circ} \mathrm{C}$ or $42^{\circ} \mathrm{C}$ in media containing prostaglandin $\mathrm{A}_{1}\left(\mathrm{PGA}_{1}\right)$ or saline (Control) for $20 \mathrm{~h}$.

\section{Impact of Endocrine System on Cellular HS Response}

As stated earlier, the process of acclimation is under endocrine regulation. However, until recently, it was not apparent the endocrine system was directly involved with regulating the intracellular HS response. It is now clear (as shown in Figures 2 and 3 and Table 1) that a variety of endocrine or paracrine signals associated with a range of stressors modify the intracellular HS response. Additional studies in our laboratory indicate that melatonin and prolactin also upregulate HSP 70 gene expression in BMEC during HS, whereas leptin downregulates its expression (data not shown). As stated previously, PGA increases HSP gene expression via increased HSF1 activation. However, very little is known about how other hormones govern increases in HSP gene expression. Collectively, the data in Table 1 lend credence to the concept of the HS response as a whole-body phenomenon with intracellular, tissue, and systemic components. Very little work has been done to evaluate the relationship between systemic hormonal response to HS and regulation of the tissue level and intracellular HS response. Two hormones known to increase in plasma in response to thermal stress (prolactin and glucocorticoids) are associated with modifying the intracellular HS response. When glucocorticoids enter the cytoplasm they cause the release of preformed cytoplasmic HSP 70 and 90, which are bound to the glucocorticoid receptor. This preformed HSP constitutes the first line of defense against HS because the proteins are already in the cytoplasm and do not require synthesis. Release of the HSP in response to increased glucocorticoid binding to its receptor provides an instant pool of HSP to protect against protein denaturation. The hormone-receptor complex then moves into the nucleus where, among other actions, it enhances expression of HSP genes (Vijayan et al., 2003). Prolactin 
Table 1. Partial list of hormones affecting heat shock protein (HSP) gene expression or protein activity

\begin{tabular}{lll}
\hline Hormone & Effect & Reference \\
\hline Insulin & Stimulates HSP gene in cardiac tissue & Li et al., 2006 \\
IGF-I & Increased HSP in epidermis of IGF transgenic mice & Shen et al., 2007 \\
Prolactin & Stimulates HSP 60 in rodent luteal cells & Stocco et al., 2001 \\
Growth hormone & Stimulates HSP in whole blood of sea bream & Deane and Woo, 2005 \\
Glucocorticoids & Increase cytosol HSP and HSP gene expression & Vijayan et al., 2003 \\
Melatonin & Increases HSP gene expression in pancreatic AR42J cells & Bonior et al., 2005 \\
Leptin & Downregulates HSP 70 in chicken liver and hypothalamus & Figueiredo et al., 2007 \\
Vasopressin & Stimulates HSP in renal tubular cells & Xu et al., 1996 \\
Catecholamines & Stimulate HSP in brown adipose tissue & Matz et al., 1996 \\
Prostaglandin A & Increased expression of HSP in bovine mammary epithelial cells, & Collier et al., 2007; Amici et al., \\
& human K562 cells, and human monocytes & $1992 ;$ Elia et al., 1999 \\
Estrogens and androgens & Increase HSP gene expression in human neurons & Zhang et al., 2004 \\
\hline
\end{tabular}

also modifies HSP gene expression (Table 1), although the mechanism is unknown and prolactin's role in seasonal changes in cognate and inducible forms of HSP 70 remains to be determined.

\section{SYSTEMIC HEAT SHOCK RESPONSE}

The importance of the endocrine system mediating acclimation to environmental stress, growth, and metabolism is clear and therefore it is not surprising that thermal stress has a profound effect on circulating hormones. Many thermal stress-induced hormonal alterations have been known for several decades (see reviews by Johnson and Vanjonack, 1976; Collier et al., 1982). For example, hyperthermia depresses thyroid function, presumably to depress metabolic heat generation. Prolactin, a hormone important for galactopoiesis and lacatational persistency, is elevated during thermal stress although the mechanistic basis is not well understood. Stress-response hormones (glucocorticoids) are elevated during initial HS exposure and then become depressed with prolonged periods of thermal stress. Recent studies in lactating dairy cows demonstrate that HS elevates plasma insulin concentrations (Itoh et al., 1998; Wheelock et al., 2006) and this may be important for glucose disposal in peripheral tissues.

Few experiments have evaluated the effects of HS on endocrine parameters while simultaneously providing proper controls accounting for changes in nutrient intake. Animals in positive energy balance have a coupled somatotropic axis, defined as efficient growth hormone (GH)-dependent IGF-I synthesis and secretion by the liver in response to pituitary-derived or exogenous somatotropin (ST; Bauman and Vernon, 1993). However, during periods of negative energy balance such as malnutrition or when the energy demands of milk production exceeds energy intake (i.e., early lactation), circulating ST concentrations rise and plasma IGF-I concentrations fall. During these physiological states, the response of hepatic IGF-I production to exogenous bST is negligible at best (Bauman and Vernon, 1993). Taken together, these observations indicate that the somatotropic axis becomes uncoupled during periods of negative energy balance (Bauman and Vernon, 1993). Despite the reduced nutrient intake, some researchers have reported numerical or statistically significant reductions in ST levels during thermal stress (Mitra et al., 1972; Mohammed and Johnson, 1985; McGuire et al., 1991). However, we have recently reported no differences in mean GH concentrations, GH pulsatility characteristics, or GH response to growth hormone releasing factor in heat-stressed vs. pair-fed thermoneutral controls (Rhoads et al., 2007). Circulating IGF-I has been implicated in the regulation of milk synthesis in dairy cattle and blood-borne IGF-I is produced in a GHdependent fashion by the liver (Boisclair et al., 2006). Therefore, we investigated whether hepatic GH responsiveness was altered with high ambient temperature by measuring proximal indicators [i.e., GH receptor abundance and signal transducer and activator of transcription (STAT)-5 phosphorylation] of GH signaling (Rhoads et al., 2007). Heat stress, independent of reduced feed intake, decreased abundance of the GH receptor; however, both HS and malnutrition were sufficient to decrease STAT-5 phosphorylation. Consistent with reduced GH signaling through STAT-5, hepatic IGF-I mRNA abundance was lower in HS and underfed thermoneutral animals. Thus, the reduced hepatic GH responsiveness (in terms of IGF-I gene expression) observed during HS appears to involve mechanisms associated with a reduction in feed intake. The physiological significance of reduced hepatic GH receptor abundance during HS is unclear at this time but may serve to alter other GH-dependent hepatic processes such as regulation of gluconeogenesis.

\section{Extracellular HSP}

Recently, it has been demonstrated that HSP 70 is present in the extracellular compartment in rats, hu- 
mans, and cattle (Kristensen et al., 2004; Fleshner and Johnson, 2005) and that plasma levels of HSP 70 are increased by a variety of stressors (Johnson et al., 2005; Aneja et al., 2006). Release of extracellular HSP is associated with $\alpha_{1^{-}}$and $\beta$-adrenergic receptor activation, and blocking these receptors abolishes exercise-induced increases in plasma HSP (Johnson et al., 2005). Secretion of HSP 70 from mammalian cells has been demonstrated to occur through a nonclassical pathway involving lysosomal endosomes (Mambula and Calderwood, 2006) because HSP 70 does not contain a consensus secretory signal sequence. Necrotic cells and cells undergoing apoptosis are also possible sources of extracellular HSP (Mambula and Calderwood, 2006). Once in the extracellular compartment, HSP 70 has been shown to facilitate innate immunity (Campisi et al., 2003; Fleshner and Johnson, 2005; Aneja et al., 2006). Exercise increases plasma HSP 70 concentration and this increase can be attenuated by glucose ingestion and adaptation to exercise (Febbraio et al., 2004; Marshall et al., 2006). Although HSP 70 is present in plasma of Holstein-Friesian cattle (Kristensen et al., 2004) there have been no studies evaluating the impact of various stressors on plasma concentrations and what, if any, role extracellular HSP has on the immune and or the endocrine system of cattle.

\section{Metabolic Changes}

Despite the enormous economic impact, there is little information on the HS-induced changes in metabolism and nutrient partitioning in lactating dairy cattle. An increased heat load decreases nutrient uptake in almost all species and the dairy cow appears particularly sensitive as decreased DMI $>30 \%$ is not uncommon. It is traditionally assumed that decreased DMI is primarily responsible for reduced milk yield (Fuquay, 1981; West, 1999). However, we have recently demonstrated that inadequate nutrient intake accounts for only $~ 40 \%$ of the reduced milk yield and we hypothesize that changes in carbohydrate metabolism are responsible for a large portion of the remainder (Wheelock et al., 2006; Rhoads et al., 2007).

In contrast to monogastrics, ruminants absorb very little glucose from their diet, and peak gluconeogenesis rates occur immediately after a meal. Complex carbohydrates are fermented in the rumen and the major end products are acetate, butyrate, and propionate. Propionate is the primary gluconeogenic precursor, but depending upon the energetic state, the contribution of amino acids, lactate, and glycerol increase to meet glucose demands.

Glucose metabolism is greatly influenced by a variety of stimuli including hormones, cytokines, and physio- logical state (i.e., pregnancy, lactation, malnutrition and disease), all of which increase the rate of hepatic gluconeogenesis (Bauman and Vernon, 1993; Velez and Donkin, 2004; 2005; Williams et al., 2006). A strong relationship between mRNA abundance for gluconeogenic enzymes and their activity has been demonstrated in cattle during various physiological states (Greenfield et al., 2000). Hormones, such as glucagon and catecholamines, act to regulate gluconeogenesis by enlisting the transcriptional coactivator, peroxisome proliferator-activated receptor- $\gamma$ coactivator- $1 \alpha$ (PGC-1 $\alpha$; reviewed in Puigserver and Spiegelman, 2003). In this scenario, glucagon and catecholamines act through the cyclic AMP pathway and cAMP response element binding protein (CREB) to stimulate PGC- $1 \alpha$ gene expression; PGC- $1 \alpha$ participates with transcription factors at the promoter level of gluconeogenic genes (i.e., phosphoenolpyruvate carboxykinase 1; PEPCK) to activate expression.

Heat stress also markedly alters glucose homeostasis in heat-stressed cows. Using a glucose tolerance test we observe greater glucose disposal (rate of glucose entry into cells) in heat-stressed compared with pair-fed thermal neutral cows (Wheelock et al., 2006). Glucose disposal differences can be reconciled by a weaker insulin response to the glucose bolus by the pair-fed thermal neutral cows, whereas the insulin response remains unchanged during heat stress. Despite similar nutrient intake, the pair-fed thermal neutral control group appears to reduce insulin-dependent glucose utilization, whereas the HS group maintains insulin-dependent glucose utilization. Next, we asked whether changes in glucose metabolism were restricted to peripheral tissues (i.e., skeletal muscle and adipose tissue) or involved the liver, the primary site of glucose production in ruminants. We examined hepatic expression of key gluconeogenic genes and found that feed restriction during thermal neutral conditions stimulated the expression of PGC- $1 \alpha$, PEPCK, and pyruvate carboxylase (PC). In contrast, discordant changes (PC increased but PGC- $1 \alpha$ and PEPCK were unaltered) in gluconeogenic gene expression was evident during heat stress (Wheelock et al., 2006). Based on this information, it appears that hepatic adaptation to reduced nutrient intake, in terms of glucose metabolism, differs with variations in environmental temperature.

\section{ACCLIMATION}

Acclimation is a "within lifetime phenotypic response" to environmental stress and is a homeorhetic process driven by the endocrine system (Horowitz, 2001; Collier et al., 2004). Evidence to date indicates that the alterations in gene expression and changes in 
cellular signaling are key components of this process (Horowitz, 2001). The time required for acclimation varies by tissue type and ranges from a few days to several weeks. For example, changes in metabolism in response to HS occur over a few days (Rhoads et al., 2007), whereas changes in hair coat require several weeks. Changes in gene expression in response to HS that are associated with acclimation include elevation of the constitutive HSP system, reduced threshold for systemic HS responses, and altered sensitivity to homeostatic signals such as insulin and catecholamines (Horowitz, 2001). These changes are associated with altered nutrient partitioning and may therefore be associated with a portion of the production losses that occur during thermal stress. However, the control mechanisms at the gene transcription and translation level involved have not been elucidated and should be a major focus of future studies in this area.

\section{SUMMARY}

Gene networks within and across cells and tissues respond to environmental heat loads above the thermoneutral zone with both intra- and extracellular signals that coordinate cellular and whole-animal metabolism. Activation of these systems appears to be initiated at skin surface temperatures exceeding $35^{\circ} \mathrm{C}$ as animals begin to store heat and rapidly increase EVHL mechanisms. Gene expression changes include 1) activation of HSF1; 2) increased expression of HSP and decreased expression and synthesis of other proteins; 3) increased glucose and amino acid oxidation and reduced fatty acid metabolism; 4) endocrine system activation of the stress response; and 5) immune system activation via extracellular secretion of HSP. If the stress persists, these gene expression changes lead to an altered physiological state referred to as acclimation, a process largely controlled by altered gene expression in response to endocrine signals. In the acclimated state, metabolism is adjusted to minimize detrimental effects of increased thermal heat load. The role of secreted HSP in feedback regulation of the immune and endocrine system in the bovine has not yet been investigated. The variation in EVHL among animals and the central role that HSF1 has in coordinating thermal tolerance suggest that there is opportunity to improve thermotolerance via manipulation of the genes controlling expression of HSF1 and those regulating EVHL in cattle. Determining the basis for altered energy metabolism during thermal stress will lead to opportunities for improved animal performance via altered nutritional management.

\section{REFERENCES}

Akerfelt, M., D. Trouillet, V. Mezger, and L. Sistonen. 2007. Heat shock factors at a crossroad between stress and development. Ann. N.Y. Acad. Sci. 1391:1-13.
Amici, C., L. Sistonen, M. G. Santoro, and R. I. Morimoto. 1992. Antiproliferative prostaglandins activate heat shock transcription factor. Proc. Natl. Acad. Sci. USA 89:6227-6231.

Aneja, R., K. Odoms, K. Dunsmore, T. P. Shanly, and H. R. Wong. 2006. Extracellular heat shock protein-70 induces endotoxin tolerance in THP-1 cells. J. Immunol. 177:7184-7192.

Bauman, D. E., and R. G. Vernon. 1993. Effects of exogenous bovine somatotropin on lactation. Annu. Rev. Nutr. 13:437-461.

Berman, A. 2005. Estimates of heat stress relief needs for Holstein dairy cows. J. Anim. Sci. 83:1377-1384.

Bonior, J., J. Jaworek, S. J. Konturek, and W. W. Pawlik. 2005. Increase of heat shock protein gene expression by melatonin in AR42J cells. J. Physiol. Pharmacol. 56:471-481.

Boisclair, Y. B., S. R. Wesolowski, J. W. Kim, and R. A. Ehrhardt. 2006. Roles of growth hormone and leptin in the periparturient dairy cow. Pages 327-346 in Running Physiology: Digestion, Metabolism and Impact of Nutrition on Gene Expression, Immunology and Stress. K. Sejrsen, T. Hvelplund, and M. O. Nielsen, ed. Wageningen Academic Publishers. Wageningen, the Netherlands.

Campisi, J., T. H. Leem, and M. Fleshner. 2003. Stress-induced extracellular Hsp-72 is a functionally significant danger signal to the immune system. Cell Stress Chaperones 8:272-286.

Collier, J. L., M. B. Abdallah, L. L. Hernandez, J. V. Norgaard, and R. J. Collier. 2007. Prostaglandins $\mathrm{A}_{1}\left(\mathrm{PGA}_{1}\right)$ and $\mathrm{E}_{1}\left(\mathrm{PGE}_{1}\right)$ alter heat shock protein 70 (HSP-70) gene expression in bovine mammary epithelial cells (BMEC). J. Dairy Sci. 90(Suppl 1.):62. (Abstr.)

Collier, R. J., L. H. Baumgard, A. L. Lock, and D. E. Bauman. 2004. Physiological limitations, nutrient partitioning. Pages 351-378 in Yields of Farmed Species: Constraints and Opportunities in the 21st Century. J. Wiseman and R. Sylvestor, ed. Nottingham Univ. Press. Nottingham, UK.

Collier, R. J., D. K. Beede, W. W. Thatcher, L. A. Israel, and C. J. Wilcox. 1982. Influences of environment and its modification on dairy animal health and production. J. Dairy Sci. 65:2213-2227.

Collier, R. J., C. M. Stiening, B. C. Pollard, M. J. VanBaale, L. H. Baumgard, P. C. Gentry, and P. M. Coussens. 2006. Use of gene expression microarrays for evaluating environmental stress tolerance at the cellular level in cattle. J. Anim. Sci. 84(E Suppl.):E1-E13.

Da Silva, R. G., N. La Scala, Jr., and H. Tonhati. 2003. Radiative properties of the skin and haircoat of cattle and other animals. Trans. ASAE 46:913-918.

Deane, E. E., and N. Y. Woo. 2005. Growth hormone increases hsc70/ hsp70 expression and protects against apoptosis in whole blood preparations from silver sea bream. Ann. N. Y. Acad. Sci. 1040:288-292.

Dokladny, K., W. Wharton, R. Lobb, T. Y. Ma, and P. L. Moseley. 2006. Induction of physiological thermotolerance in MDCK monolayers: Contribution of heat shock protein 70. Cell Stress Chaperones 11:268-275.

Ella, G., B. Polla, A. Rossi, and M. G. Santoro. 1999. Induction of ferritin and heat shock proteins by prostaglandin $A_{1}$ in human monocytes. Eur. J. Biochem. 264:736-745.

Febbraio, M. A., J. L. Mesa, J. Chung, A. Steensberg, C. Keller, H. B. Nielson, P. Krustrup, P. Ott, N. H. Secher, and B. K. Pederson. 2004. Glucose ingestion attenuates the exercise-induced increase in circulating heat shock protein 72 and heat shock protein 60 in humans. Cell Stress Chaperones 9:390-396.

Figueiredo, D., A. Gertler, G. Cabello, E. Decupere, J. Buyse, and S. Dridi. 2007. Leptin downregulates heat shock protein-70 (HSP70) gene expression in chicken liver and hypothalamus. Cell Tissue Res. 329:91-101.

Fleshner, M., and J. D. Johnson. 2005. Endogenous extracellular heat shock protein 72: Releasing signal(s) and function. Int. J. Hyperthermia 21:457-471.

Fuquay, J. W. 1981. Heat stress as it affects production. J. Anim. Sci. $52: 167-174$.

Gebremedhin, K. G., and B. Wu. 2001. Sensible and latent heat losses from wet-skin surface and fur layer. ASAE Annual International 
Meeting, Sacramento, CA. ASAE Paper No. 01-4040. ASABE, St. Joseph, MI.

Greenfield, R. B., M. J. Cecava, and S. S. Donkin. 2000. changes in MRNA expression for gluconeogenic enzymes in liver of dairy cattle during the transition to lactation. J. Dairy Sci. 83:12281236.

Horowitz, M. 2001. Heat acclimation: Phenotypic plasticity and cues to the underlying molecular mechanisms. J. Therm. Biol. 26:357-363.

Itoh, F., Y. Obara, M. T. Rose, H. Fuse, and H. Hashimoto. 1998. Insulin and glucagon secretion in lactating cows during heat exposure. J. Anim. Sci. 76:2182-2189.

Johnson, H. D., and W. J. Vanjonack. 1976. Effects of environmental and other stressors on blood hormone patterns in lactating animals. J. Dairy Sci. 59:1603-1617.

Johnson, J. D., J. Campisi, C. M. Sharkey, S. L. Kennedy, M. Nickerson, and M. Fleshner. 2005. Adrenergic receptors mediate stressinduced elevations in extracellular Hsp 72. J. Appl. Physiol. 99:1789-1795.

Klungland, H., and D. I. Vage. 2003. Pigmentary switches in domestic animal species. Ann. N.Y. Acad. Sci. 994:331-338.

Kristensen, T. N., P. Løvendahl, P. Berg, and V. Loeschcke. 2004. Hsp 72 is present in plasma from Holstein-Friesian dairy cattle, and the concentration level is repeatable across days and age classes. Cell Stress Chaperones 9:143-149.

Lanks, K. W. 1986. Modulators of the eukaryotic heat shock response. Exp. Cell Res. 165:1-10.

Lee, W. C., H. C. Wen, C. P. Chang, M. Y. Chen, and M. T. Lin. 2006. Heat shock protein 72 overexpression protects against hyperthermia, circulatory shock and cerebral ischemia during heat stroke. J. Appl. Physiol. 100:2073-2082.

Li, G., I. S. Ali, and R. W. Currie. 2006. Insulin induces myocardial protection and Hsp70 localization to plasma membranes in rat hearts. Am. J. Physiol. Heart Circ. Physiol. 291:H1709-H1721.

Lindquist, S. 1986. The heat-shock response. Annu. Rev. Biochem. 55:1151-1191.

Mambula, S. S., and S. K. Calderwood. 2006. Heat shock protein 70 is secreted from tumor cells by a nonclassical pathway involving lysosomal endosomes. J. Immunol. 177:7849-7857.

Mariasegaram, M., C. C. Chase, J. X. Chaparro, T. A. Olson, R. A. Brenneman, and R. P. Niedz. 2007. The slick hair locus maps to chromosome 20 in Senepol-derived cattle. Anim. Genet. 38:54-59.

Marshall, H. C., R. A. Ferguson, and M. A. Nimmo. 2006. Human resting extracellular heat shock protein 72 concentration decreases during the initial adaptation to exercise in a hot humid environment. Cell Stress Chaperones 11:129-134.

Matz, J. M., K. P. LaVoi, and M. J. Blake. 1996. Adrenergic regulation of the heat shock response in brown adipose tissue. J. Pharmacol Exp. Ther. 277:1751-1758.

McCutcheon, L. J., and R. J. Geor. 2000. Influence of training on sweating responses during submaximal exercise in horses. J. Appl. Physiol. 89:2463-2471.

McGuire, M. A., D. K. Beede, R. J. Collier, F. C. Buonomo, M. A. DeLorenzo, C. J. Wilcox, G. B. Hutington, and C. K. Reynolds. 1991. Effects of acute thermal stress and amount of feed intake on concentrations of somatotropin, insulin-like growth factor (IGF)-I and IGF-II, and thyroid hormones in plasma of lactating Holstein cows. J. Anim. Sci. 69:2050-2056.

Mitra, R., G. I. Christison, and H. D. Johnson. 1972. Effect of prolonged thermal exposure on growth hormone $(\mathrm{GH})$ secretion in cattle. J. Anim. Sci. 34:776-779.

Mohammed, M. E., and H. D. Johnson. 1985. Effect of growth hormone on milk yields and related physiological functions of Holstein cows exposed to heat stress. J. Dairy Sci. 68:1123-1133.

Olson, T. A., C. C. Chase, Jr., C. Lucena, E. Godoy, A. Zuniga, and R. J. Collier. 2006. Effect of hair characteristics on the adaptation of cattle to warm climates. 8th World Congress on Genetics Applied to Livestock Production, Belo Horizonte, Brasil.
Olson, T. A., C. Lucena, C. C. Chase, and A. C. Hammond. 2003. Evidence of a major gene influencing hair length and heat tolerance in Bos taurus cattle. J. Anim. Sci. 81:80-90.

Page, T. J., S. Sikder, L. Yang, L. Pluta, R. D. Wolfinger, T. Kodadek, and R. S. Thomas. 2006. Genome-wide analysis of human HSF1 signaling reveals a transcriptional program linked to cellular adaptation and survival. Mol. Biosyst. 2:627-639.

Pirkkala, L., P. Nykänen, and L. Sistonen. 2001. Roles of the heat shock transcription factors in regulation of the heat shock response and beyond. FASEB J. 15:1118-1131.

Pollard, B. C., M. E. Dwyer, A. C. Fitzgerald, P. C. Gentry, D. A. Henderson, and R. J. Collier. 2004. Effects of ambient temperature and solar radiation on skin evaporative water loss in dairy cattle. J. Dairy Sci. 87(Suppl. 1):198. (Abstr.)

Pollard, B. C., M. D. Estheimer, M. E. Dwyer, P. C. Gentry, W. J. Weber, E. Lemke, L. H. Baumgard, D. A. Henderson, B. A. Crooker, and R. J. Collier. 2005. The influence of parity, acclimatization to season, and recombinant bovine somatotropin (rbST) on diurnal patterns of prolactin and growth hormone in Holsteins exposed to heat stress. J. Dairy Sci. 88(Suppl. 1):121. (Abstr.)

Puigserver, P., and B. M. Spiegelman. 2003. Peroxisome proliferatoractivated receptor-gamma coactivator 1 alpha (PGC-1 alpha): Transcriptional coactivator and metabolic regulator. Endocr. Rev. 24:78-90.

Rhoads, M. L., R. P. Rhoads, S. R. Sanders, S. H. Carroll, W. J. Weber, B. A. Crooker, R. J. Collier, M. J. VanBaale, and L. H. Baumgard. 2007. Effects of heat stress on production, lipid metabolism and somatotropin variables in lactating cows. J. Dairy Sci. 90 (Suppl. 1):230. (Abstr.)

Rhoads, R. P., J. D. Sampson, M. C. Lucy, J. N. Spain, D. E. Spiers, R. J. Tempelman, and P. M. Coussens. 2005. Hepatic gene expression profiling during adaptation to a period of chronic heat stress in lactating dairy cows. FASEB J. 19:A1673.

Shen, J., P. K. Riggs, S. C. Hensley, L. J. Schroeder, A. R. Traner, K. J. Kochan, M. D. Person, and J. DiGiovanni. 2007. Differential expression of multiple anti-apoptotic proteins in epidermis of IGF1 transgenic mice as revealed by 2-dimensional gel electrophoresis/mass spectrometry analysis. Mol. Carcinog. 46:331-340.

Sonna, L. A., J. Fujita, S. L. Gaffin, and C. M. Lilly. 2002. Effects of heat and cold stress on mammalian gene expression. J. Appl. Physiol. 92:1725-1742.

Stocco, C., E. Callegari, and G. Gibori. 2001. Opposite effect of prolactin and prostaglandin $\mathrm{F} 2 \alpha$ on the expression of luteal genes as revealed by rat cDNA expression array. Endocrinology 142:4158-4161.

Suchyta, S., S. Sipkovsky, R. Kruska, A. Jeffers, A. McNulty, M. J. Coussens, R. J. Tempelman, R. G. Halgren, P. M. Saama, D. E. Bauman, Y. R. Boisclair, J. L. Burton, R. J. Collier, E. J. DePeters, T. A. Ferris, M. C. Lucy, M. A. McGuire, J. F. Medrano, T. R. Overton, T. P. Smith, G. W. Smith, T. S. Sonstegard, J. N. Spain, D. E. Spiers, J. Yao, and P. M. Coussens. 2003. Development and testing of a high-density cDNA microarray resource for cattle. Physiol. Genomics 15:158-164.

Trinklein, N. D., J. I. Murray, S. J. Hartman, D. Botsein, and R. M. Myers. 2004. The role of heat shock transcription factor 1 in the genome-wide regulation of the mammalian heat shock response. Mol. Biol. Cell 15:1254-1261.

Velez, J. C., and S. S. Donkin. 2004. Bovine somatotropin increases hepatic phosphoenolpyruvate carboxykinase mRNA in lactating dairy cows. J. Dairy Sci. 87:1325-1335.

Velez, J. C., and S. S. Donkin. 2005. Feed restriction induces pyruvate carboxylase but not phosphoenolpyruvate in dairy cows. J. Dairy Sci. 88:2938-2948.

Vijayan, M. M., S. Raptis, and R. Sathiyaa. 2003. Cortisol treatment affects glucocorticoid receptor and glucocorticoid responsive genes in the liver of rainbow trout. Gen. Comp. Endocrinol. 132:256263

West, J. W. 1999. Nutritional strategies for managing the heatstressed dairy cow. J. Anim. Sci. 77(Suppl. 2):21-35.

Winter, A., A. Alzinger, and F. Ruedi. 2007. Assessment of the gene content of the chromosomal regions flanking bovine DGAT1. Genomics 83:172-180. 
Wheelock, J. B., S. R. Sanders, G. Shwartz, L. L. Hernandez, S. H. Baker, J. W. McFadden, L. J. Odens, R. Burgos, S. R. Hartman, R. M. Johnson, B. E. Jones, R. J. Collier, R. P. Rhoads, M. J. VanBaale and L. H. Baumgard. 2006. Effects of heat stress and rbST on production parameters and glucose homeostasis. J. Dairy Sci. 89(Suppl. 1):290. (Abstr.)

Williams, E. L., S. M. Rodriguez, D. C. Beitz and S. S. Donkin. 2006. Effects of short-term glucagon administration on gluconeogenic enzymes in the liver of midlactation dairy cows. J. Dairy Sci. 89:693-703

Xu, Q., L. Ganju, T. W. Fawcett, and N. J. Holbrook. 1996. Vasopressin-induced heat shock protein expression in renal tubular cells. Lab. Invest. 74:178-187.

Zhang, Y., N. Champagne, L. K. Beitel, C. G. Goodyer, M. Trifiro, and A. LeBlanc. 2004. Estrogen and androgen protection of human neurons against intracellular amyloid 1-42 toxicity through heat shock protein 70. J. Neurosci. 24:5315-5321. 